\title{
Reduced expression of the AdipoR1 gene is correlated with venous invasion in colorectal cancer
}

\author{
NAOTO YAMAMOTO ${ }^{1}$, TAKASHI OSHIMA ${ }^{1}$, KAZUE YOSHIHARA ${ }^{1}$, TSUTOMU SATO ${ }^{1}$, ROPPEI YAMADA ${ }^{1}$, \\ SHOICHI FUJII ${ }^{1}$, YASUHIKO NAGANO ${ }^{1}$, MANABU SHIOZAWA ${ }^{2}$, MAKOTO AKAIKE $^{2}$, NOBUYUKI WADA ${ }^{3}$, \\ YASUSHI RINO ${ }^{3}$, CHIKARA KUNISAKI ${ }^{1}$, MUNETAKA MASUDA ${ }^{3}$, KATSUAKI TANAKA ${ }^{1}$ and TOSHIO IMADA ${ }^{4}$ \\ ${ }^{1}$ Gastroenterological Center, Yokohama City University Medical Center, Kanagawa-ken 232-0024; \\ ${ }^{2}$ Department of Surgery, Kanagawa Cancer Center, Kanagawa-ken 241-0815; ${ }^{3}$ Department of Surgery, \\ Yokohama City University; ${ }^{4}$ Yokohama City University, Kanagawa-ken 236-0004, Japan
}

Received November 14, 2008; Accepted May 7, 2009

DOI: $10.3892 / \mathrm{mmr} 00000136$

\begin{abstract}
Serum adiponectin concentrations are negatively correlated with body fat percentage and with the risk of colorectal cancer. However, few studies have examined the relationship between adiponectin receptor expression and colorectal cancer. We measured the expression levels of the AdipoR1 and AdipoR2 genes by quantitative real-time reverse-transcription polymerase chain reaction in 202 paired specimens of cancer tissue and adjacent normal mucosa obtained from patients with colorectal cancer. To evaluate the clinical significance of AdipoRl and AdipoR2, correlations between the expression of these genes and clinicopathological features were examined. Both genes were expressed in colorectal cancer and in adjacent normal mucosa. The expression levels of the genes were significantly higher in cancer tissue than in normal mucosa $(\mathrm{P}<0.0001)$. Reduced expression of the AdipoRl gene was correlated with venous invasion, but not with any other clinicopathological feature examined. Our findings suggest that reduced expression of the AdipoR1 gene may be a useful predictor of venous invasion.
\end{abstract}

\section{Introduction}

Obesity has been identified as a risk factor for colorectal and several other types of cancer (1-3). Adiponectin, a hormone that is secreted exclusively by adipocytes, has potent insulin-sensitizing effects. Serum adiponectin concentrations are negatively correlated with body fat percentage $(4,5)$.

Correspondence to: Dr Naoto Yamamoto, Gastroenterological Center, Yokohama City University Medical Center, 4-57 Urafune-cho, Minami-ku, Yokohama-shi, Kanagawa-ken 232-0024, Japan

E-mail: naoto-y@urahp.yokohama-cu.ac.jp

Key words: adiponectin, AdipoR1, AdipoR2, colorectal cancer, venous invasion
Hypoadiponectinemia is associated with insulin resistance and hyperinsulinemia (4). Serum adiponectin concentrations are negatively correlated with the risk of colorectal cancer (5).

Two types of adiponectin receptors (AdipoR1 and AdipoR2) have been cloned (6). In mice, AdipoR1 is expressed in various organs, including skeletal muscle, the lungs and the spleen, whereas AdipoR2 is predominantly expressed in the liver (6). In humans, AdipoR1 and AdipoR2 are expressed in pancreatic islet cells, macrophages, adipocytes and vascular smooth muscle, as well as in human breast epithelial and breast cancer cells (7-10). AdipoR1 is a receptor for globular adiponectin, whereas AdipoR2 is a receptor for full-length adiponectin (11). AdipoR1 and R2 are thought to mediate increased AMP kinase activity and peroxisome proliferator activated receptor (PPAR)- $\alpha$ ligand activity, fatty acid oxidation and glucose uptake by adiponectin (11).

A recent study showed that adiponectin inhibits the growth of gastric cancer and the development of peritoneal metastasis in vivo through AdipoR1 and AdipoR2 (12). Adiponectin also induces tumor vessel apoptosis and stimulates endothelial cell growth and angiogenesis $(13,14)$.

In this study, we measured the expression levels of the AdipoR1 and AdipoR2 genes in 202 paired specimens of cancer tissue and adjacent normal mucosa obtained from patients with colorectal cancer. To evaluate the clinical significance of AdipoR1 and AdipoR2, we examined the correlation between the expression of these genes and clinicopathological features.

\section{Materials and methods}

Patients and samples. Surgical specimens of cancer tissue and adjacent normal mucosa obtained from 202 patients with untreated colorectal carcinoma were studied. The patients underwent surgery at the Gastroenterological Center of Yokohama City University Medical Center and at Kanagawa Cancer Center between 2002 and 2006. Informed consent was obtained from each patient. The ethics committees of Yokohama City University Medical Center and Kanagawa Cancer Center approved the protocol before initiation of the study. All tissue samples were embedded in OCT compound 
Table I. PCR primers and conditions.

\begin{tabular}{llcr}
\hline Gene & \multicolumn{1}{c}{ Primer } & Annealing temperature $\left({ }^{\circ} \mathrm{C}\right)$ & Product size $(\mathrm{bp})$ \\
\hline AdipoR1 & 5'-CCAGGAAGAAGAGGAGGAG-3' & 60.0 & 166 \\
& 5'-ATGTAGCAGATAGTCGTTGTC-3' & \\
AdipoR2 & 5'-TTCTTTCTTCTCCCTTTCTCTC-3' & 57.4 \\
& 5'-CTCCCTCCCTCCCTTACC-3' & & 199 \\
$\beta$-actin & 5'-AGTTGCGTTACACCCTTTCTTGAC-3' & 60.0 \\
& 5'-GCTCGCTCCAACCGACTGC-3' & \\
\hline
\end{tabular}
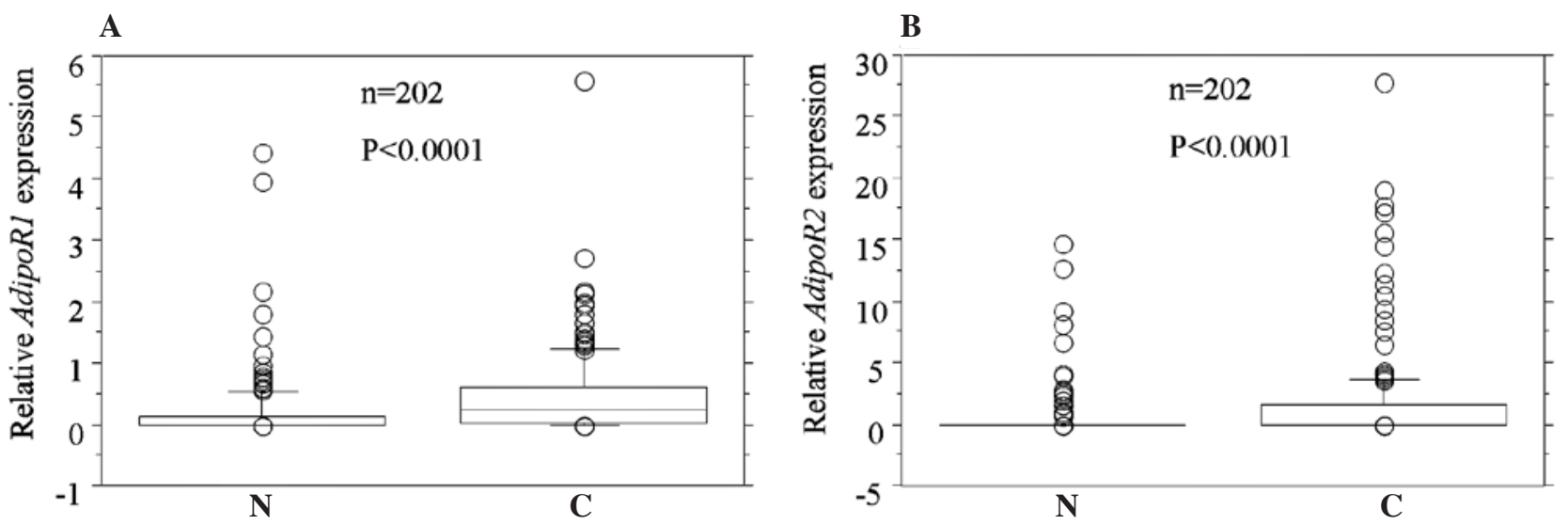

Figure 1. Comparison of AdipoR1 (A) and AdipoR2 (B) gene expression levels in colorectal cancer tissue (C) and adjacent normal mucosa (N). AdipoR1 and AdipoR2 gene expression levels were higher in cancer than in adjacent normal mucosa $(\mathrm{P}<0.0001, \mathrm{P}<0.0001$, respectively).

(Sakura Finetechnical Co., Ltd.; Tokyo) and were immediately stored at $-80^{\circ} \mathrm{C}$ until use. No patient had any other malignancies. The specimens were stained with hematoxylin and eosin and examined histopathologically. Sections that consisted of $>80 \%$ carcinoma were used to prepare total RNA.

Quantitative real-time reverse-transcription polymerase chain reaction. Total RNA isolated from colorectal cancer and adjacent normal mucosa was prepared using Trizol (Gibco, Life Tech, Gaitherburg, MD). Complementary DNA (cDNA) was synthesized from $2 \mu \mathrm{g}$ of total RNA using an iScript cDNA Synthesis Kit (Bio-Rad Laboratories, Hercules, CA). After synthesis, the cDNA was diluted 1:4 with water and stored at $-20^{\circ} \mathrm{C}$ until use. Quantitative real-time PCR was performed with an iQ SYBR Green Supermix Kit (Bio-Rad Laboratories). PCR reactions were carried out in a total volume of $15 \mu \mathrm{l}$ containing cDNA derived from $75 \mathrm{ng}$ of RNA, $0.27 \mu \mathrm{M}$ of each primer, $7.5 \mu \mathrm{l}$ of iQ SYBR Green Supermix containing dATP, dCTP, dGTP and dTTP at concentrations of $400 \mu \mathrm{M}$ each, and $50 \mathrm{U} / \mathrm{ml}$ of iTag DNA polymerase. The PCR consisted of $10 \mathrm{~min}$ at $94^{\circ} \mathrm{C}$, annealing for $30 \mathrm{sec}$ at an appropriate temperature (Table I), and a primer extension for $1 \mathrm{~min}$ at $72^{\circ} \mathrm{C}$ followed by $72^{\circ} \mathrm{C}$ for $10 \mathrm{~min}$. PCR primer sequences of AdipoR1, AdipoR 2 and $\beta$-actin, used as an internal control, are shown in Table I.
Immunohistochemical analysis of AdipoR1. Sections (4- $\mu \mathrm{m})$ were prepared from paraffin blocks, deparaffinized, rehydrated, microwaved for $15 \mathrm{~min}$ in $10 \mathrm{mmol} / \mathrm{l}$ citrate buffer (pH 6.0), and incubated for $10 \mathrm{~min}$ in Peroxidase Blocking Reagent (Dako, Glostrup, Denmark). After incubation in 5\% skim milk for $10 \mathrm{~min}$ at room temperature, the slides were incubated for $1 \mathrm{~h}$ with the primary antibodies at room temperature. The primary antibody used was rabbit antihuman AdipoR1 (raised against amino acid residues 357-375) antiserum (Phoenix Pharmaceuticals Inc., Belmont, CA, USA) at a dilution of 1:500. The secondary antibody was peroxidaselabeled polymer, EnVision+ rabbit (Dako), applied for $60 \mathrm{~min}$ at room temperature. The color reaction was developed with 3,3'-diaminobenzidine (Dako), and the slides were counterstained with hematoxylin.

Statistical analysis. Gene expression levels of colorectal cancer were compared with those of the normal adjacent mucosa using the Wilcoxon test. Relationships between gene expression and potential explanatory variables, including age, gender, tumor size, histological type, depth of invasion, lymph node metastasis, location, lymphatic invasion, venous invasion and liver metastasis, were evaluated using the $\chi^{2}$ test. Associations between variables were assessed using the Mann-Whitney U test. All statistical analysis was performed using Statview J 5.0 software 
Table II. Relationship between expression of the AdipoR1 or AdipoR2 gene and clinicopathological features.

\begin{tabular}{|c|c|c|c|c|c|c|}
\hline \multirow[b]{2}{*}{ Variables/categories } & \multicolumn{2}{|c|}{ AdipoRl expression } & \multirow[b]{2}{*}{ P-value } & \multicolumn{2}{|c|}{ AdipoR2 expression } & \multirow[b]{2}{*}{$\mathrm{P}$-value } \\
\hline & Low $(\mathrm{n}=101)$ & $\operatorname{High}(\mathrm{n}=101)$ & & Low $(n=101)$ & $\operatorname{High}(\mathrm{n}=101)$ & \\
\hline Age & $66.0 \pm 10.7$ & $65.3 \pm 10.9$ & & $66.9 \pm 11.0$ & $64.5 \pm 10.6$ & \\
\hline \multicolumn{7}{|l|}{ Gender } \\
\hline Male & 49 & 61 & 0.090 & 51 & 59 & 0.258 \\
\hline Female & 52 & 40 & & 50 & 42 & \\
\hline \multicolumn{7}{|l|}{ Location } \\
\hline Colon & 54 & 55 & 0.888 & 55 & 54 & 0.888 \\
\hline Rectum & 47 & 46 & & 46 & 47 & \\
\hline \multicolumn{7}{|l|}{ Size } \\
\hline$\leq 5 \mathrm{~cm}$ & 56 & 56 & 1.000 & 53 & 59 & 0.396 \\
\hline$>5 \mathrm{~cm}$ & 45 & 45 & & 48 & 42 & \\
\hline \multicolumn{7}{|l|}{ Histological type } \\
\hline Well differentiated & 31 & 28 & 0.774 & 27 & 32 & 0.724 \\
\hline Moderately differentiated & 55 & 60 & & 59 & 56 & \\
\hline Poorly differentiated & 15 & 13 & & 15 & 13 & \\
\hline \multicolumn{7}{|l|}{ Depth of invasion } \\
\hline $\mathrm{Tl}$ & 10 & 7 & 0.123 & 8 & 9 & 0.154 \\
\hline $\mathrm{T} 2$ & 38 & 55 & & 39 & 54 & \\
\hline $\mathrm{T} 3$ & 46 & 34 & & 47 & 33 & \\
\hline $\mathrm{T} 4$ & 7 & 5 & & 7 & 5 & \\
\hline \multicolumn{7}{|l|}{ Lymph node metastasis } \\
\hline Absent & 44 & 49 & 0.480 & 49 & 44 & 0.480 \\
\hline Present & 57 & 52 & & 52 & 57 & \\
\hline \multicolumn{7}{|l|}{ Lymphatic invasion } \\
\hline Absent & 63 & 69 & 0.442 & 66 & 66 & 1.000 \\
\hline Present & 38 & 32 & & 35 & 35 & \\
\hline \multicolumn{7}{|l|}{ Venous invasion } \\
\hline Absent & 27 & 48 & 0.002 & 33 & 42 & 0.190 \\
\hline Present & 74 & 53 & & 68 & 59 & \\
\hline \multicolumn{7}{|l|}{ Liver metastasis } \\
\hline Absent & 71 & 69 & 0.760 & 69 & 71 & 0.760 \\
\hline Present & 30 & 32 & & 32 & 30 & \\
\hline
\end{tabular}

(Abacus, CA). Two-sided P-values were calculated, and a P-value $<0.05$ was considered to indicate statistical significance.

\section{Results}

Comparison of AdipoR1 and AdipoR2 mRNA expression in colorectal cancer tissue and adjacent normal mucosa. AdipoR1 and AdipoR2 gene expression levels were higher in cancer than in adjacent normal mucosa $(\mathrm{P}<0.0001$ and $<0.0001$, respectively) (Fig. 1).
Relationship between AdipoR1 and AdipoR2 gene expression and clinicopathological features. The expression levels of the AdipoR1 and AdipoR2 genes were categorized as low or high according to their median values. The relationships between the expression of these genes and clinicopathological features were then examined. Reduced expression of AdipoRl was correlated with venous invasion $(\mathrm{P}=0.002)$. AdipoR 1 and AdipoR2 expression levels were unrelated to age, gender, tumor location, tumor size, histological type, depth of invasion, lymph node metastasis, lymphatic invasion and liver metastasis (Table II). 
A

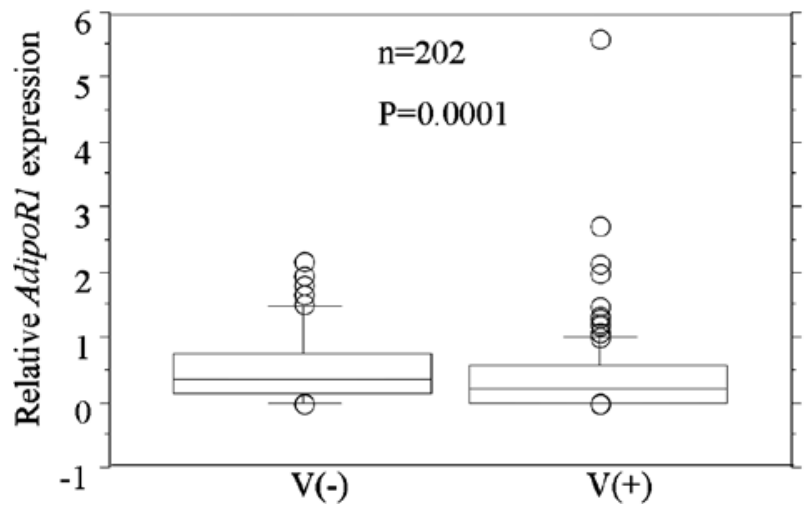

B

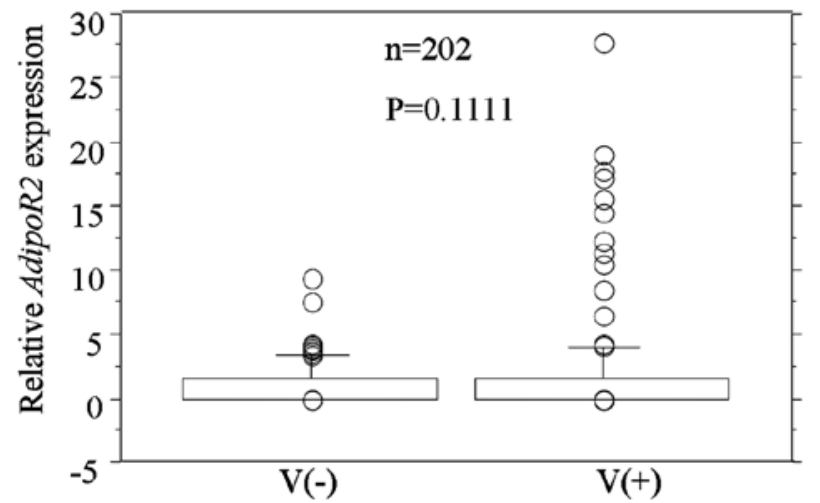

Figure 2. Association of AdipoR1 (A) and AdipoR2 (B) gene expression levels with venous invasion in 202 patients with colorectal cancer. Box boundaries, the 25th and 75th percentiles of the observed values; capped bars, the 10th and 90th percentiles; solid line, median. P-values were calculated by the MannWhitney U test. AdipoRl gene expression was higher in the absence V(-) than in the presence $\mathrm{V}(+)$ of venous invasion $(\mathrm{P}=0.0001)$.

A

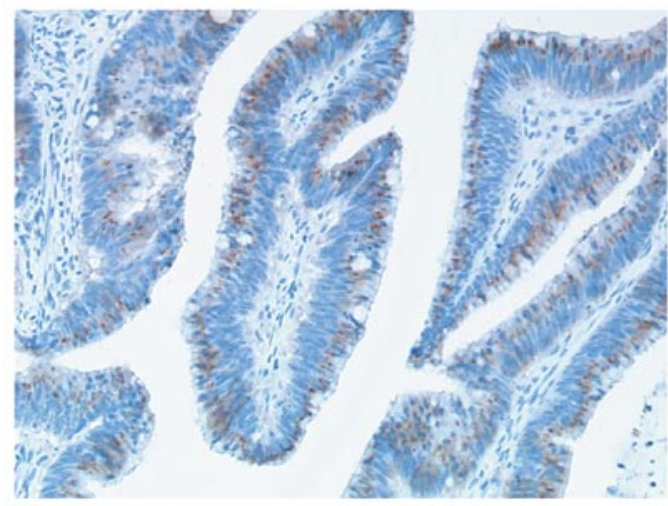

C

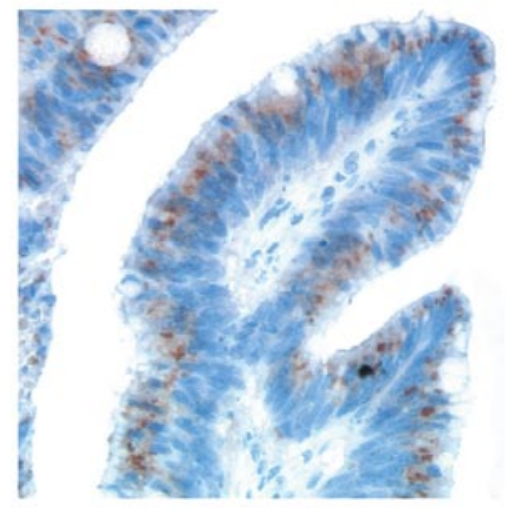

B

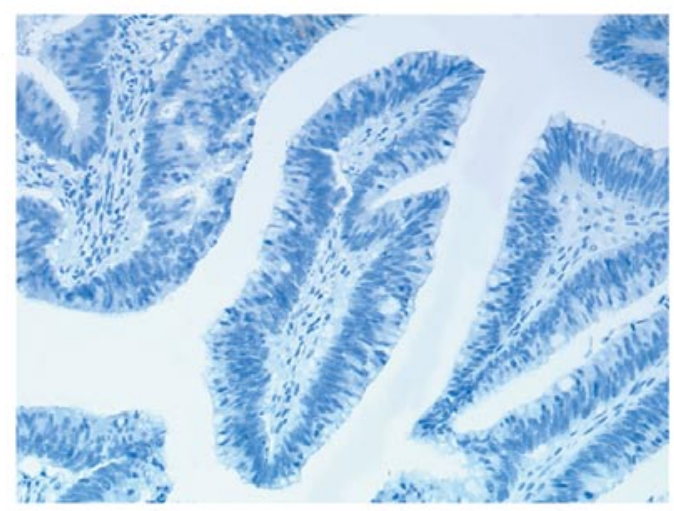

D

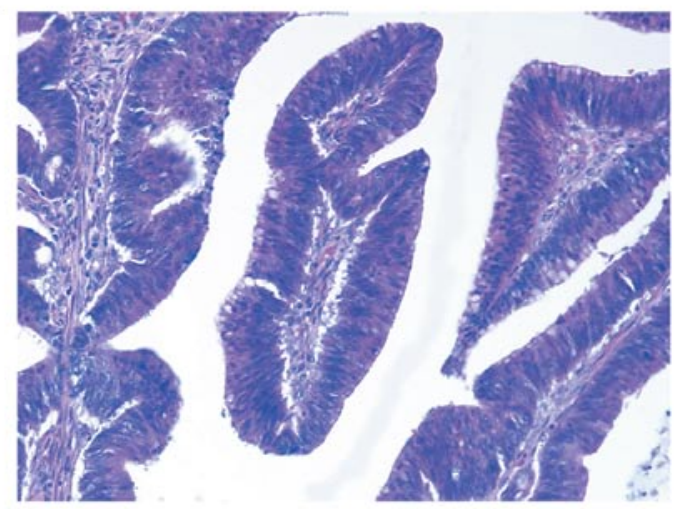

Figure 3. Immunostaining of AdipoR1 in human colorectal cancer tissue. Immunohistochemical staining of AdipoR1 in surgically resected colorectal cancer tissues (A, x200; C, x400). Negative control (B, x200). Hematoxylin and eosin staining (D, x200). AdipoR1 was positively detected in the cytoplasm of cancer cells expressing high levels of AdipoR1 mRNA.

Association of AdipoR1 and AdipoR2 gene expression with venous invasion in patients with colorectal cancer. AdipoRI gene expression levels were higher in the absence than in the presence of venous invasion ( $\mathrm{P}=0.0001)$ (Fig. 2).

Immunohistochemical analysis of AdipoR1. Upon immunohistochemical analysis, tumor tissue expressing high levels of AdipoR 1 mRNA showed positive expression of adiponectin receptor AdipoR1 (Fig. 3).

\section{Discussion}

Although many studies have examined the relationship between adiponectin and cancer (5,15-17), the relationship between adiponectin receptors and cancer remains largely unexplored (18). Takahata et al (10) suggested that adiponectin modulates the growth of cancer cells directly through AdipoR1 and AdipoR2. In this study, we examined the expression levels of the AdipoR1 and AdipoR 2 genes and 
the relationships between these levels and clinicopathological variables.

First, we compared the relative expression of the AdipoR1 and AdipoR2 genes in colorectal cancer tissue and adjacent normal mucosa. Several studies have previously assessed the expression of AdipoR1 and AdipoR2 in cancer tissue. Takahata et al (10) examined the expression of the AdipoRl and AdipoR2 genes in four breast cancer cell lines. AdipoRl and AdipoR2 gene expression was found in all cancer cell lines and in normal breast epithelial cells. More recently, Williams et al (19) studied the expression of AdipoR1 and AdipoR2 in 40 colorectal carcinomas and 12 non-tumor colorectal tissue specimens from patients with colorectal cancer. AdipoR1 was expressed in $95 \%$ of the cancer tissue specimens and $8 \%$ of the non-tumor colorectal tissue specimens. AdipoR2 was expressed in $88 \%$ of the cancer tissue specimens and $0 \%$ of the non-tumor tissue specimens. In the present study, we found that the AdipoR1 and AdipoR2 genes were expressed in colorectal cancer tissue, as well as in normal colorectal mucosa.

We went on to examine the correlation between AdipoRl and AdipoR2 gene expression and clinicopathological features. Several studies have investigated correlations between serum adiponectin concentrations and venous invasion by cancer cells $(20,21)$, To our knowledge, however, no previous study has examined the correlation between the expression of adiponectin receptors and venous invasion. Our study showed that reduced expression of the AdipoRl gene was correlated with venous invasion in colorectal cancer. These results are partially consistent with the findings of previous studies. Horiguchi et al (22) found no significant association between total adiponectin and venous invasion in renal cell carcinoma. In another study performed by the same group, the serum concentration of leptin, another adipokine, was significantly higher in patients with renal cell carcinoma who had venous invasion than in those without (20). On the other hand, Ishikawa et al (21) reported that venous invasion and lymph node metastasis tended to be more frequent in gastric cancer patients with low serum adiponectin concentrations than in those with high adiponectin concentrations. Their results suggested that adiponectin may prevent tumor invasion or metastasis.

In conclusion, our results show that reduced expression of the AdipoRl gene is correlated with venous invasion in colorectal cancer. Our findings suggest that reduced expression of AdipoR 1 may be a useful predictor of venous invasion.

\section{References}

1. Wolk A, Gridley G, Svensson M, et al: A prospective study of obesity and cancer risk (Sweden). Cancer Causes Control 12: 13-21, 2001.

2. Giovannucci E, Ascherio A, Rimm EB, Colditz GA, Stampfer MJ and Willett WC: Physical activity, obesity, and risk for colon cancer and adenoma in men. Ann Intern Med 122: 327-334, 1995.
3. Moghaddam AA, Woodward M and Huxley R: Obesity and risk of colorectal cancer: a meta-analysis of 31 studies with 70,000 events. Cancer Epidemiol Biomarkers Prev 16: 2533-2547, 2007.

4. Trujillo ME and Scherer PE: Adiponectin - journey from an adipocyte secretory protein to biomarker of the metabolic syndrome. J Intern Med 257: 167-175, 2005.

5. Wei EK, Giovannucci E, Fuchs CS, Willett WC and Mantzoros CS: Low plasma adiponectin levels and risk of colorectal cancer in men: a prospective study. J Natl Cancer Inst 97: 1688-1694, 2005.

6. Yamauchi T, Kamon J, Ito Y, et al: Cloning of adiponectin receptors that mediate antidiabetic metabolic effects. Nature 423: 762-769, 2003.

7. Kharroubi I, Rasschaert J, Eizirik DL and Cnop M: Expression of adiponectin receptors in pancreatic beta cells. Biochem Biophys Res Commun 312: 1118-1122, 2003.

8. Chinetti G, Zawadski C, Fruchart JC and Staels B: Expression of adiponectin receptors in human macrophages and regulation by agonists of the nuclear receptors PPARalpha, PPARgamma, and LXR. Biochem Biophys Res Commun 314: 151-158, 2004.

9. Berner HS, Lyngstadaas SP, Spahr A, et al: Adiponectin and its receptors are expressed in bone-forming cells. Bone 35: 842-849, 2004.

10. Takahata C, Miyoshi Y, Irahara N, Taguchi T, Tamaki Y and Noguchi S: Demonstration of adiponectin receptors 1 and 2 mRNA expression in human breast cancer cells. Cancer Lett 250: 229-236, 2007.

11. Kadowaki $\mathrm{T}$ and Yamauchi $\mathrm{T}$ : Adiponectin and adiponectin receptors. Endocr Rev 26: 439-451, 2005.

12. Ishikawa M, Kitayama J, Yamauchi T, et al: Adiponectin inhibits the growth and peritoneal metastasis of gastric cancer through its specific membrane receptors AdipoR1 and AdipoR2. Cancer Sci 98: 1120-1127, 2007.

13. Brakenhielm E, Veitonmaki N, Cao R, et al: Adiponectin-induced antiangiogenesis and antitumor activity involve caspase-mediated endothelial cell apoptosis. Proc Natl Acad Sci USA 101: 2476-2481, 2004.

14. Ouchi N, Kobayashi H, Kihara S, et al: Adiponectin stimulates angiogenesis by promoting cross-talk between AMP-activated protein kinase and Akt signaling in endothelial cells. J Biol Chem 279: 1304-1309, 2004.

15. Miyoshi Y, Funahashi T, Kihara S, et al: Association of serum adiponectin levels with breast cancer risk. Clin Cancer Res 9: 5699-5704, 2003.

16. Barb D, Pazaitou-Panayiotou K and Mantzoros CS: Adiponectin: a link between obesity and cancer. Expert Opin Investig Drugs 15: 917-931, 2006.

17. Housa D, Housova J, Vernerova Z and Haluzik M: Adipocytokines and cancer. Physiol Res 55: 233-244, 2006.

18. Mistry T, Digby JE, Chen J, Desai KM and Randeva HS: The regulation of adiponectin receptors in human prostate cancer cell lines. Biochem Biophys Res Commun 348: 832-838, 2006.

19. Williams CJ, Mitsiades N, Sozopoulos E, et al: Adiponectin receptor expression is elevated in colorectal carcinomas but not in gastrointestinal stromal tumors. Endocr Relat Cancer 15: 289-299, 2008.

20. Horiguchi A, Sumitomo M, Asakuma J, et al: Increased serum leptin levels and over expression of leptin receptors are associated with the invasion and progression of renal cell carcinoma. J Urol 176: 1631-1635, 2006.

21. Ishikawa M, Kitayama J, Kazama S, Hiramatsu T, Hatano K and Nagawa H: Plasma adiponectin and gastric cancer. Clin Cancer Res 11: 466-472, 2005

22. Horiguchi A, Ito K, Sumitomo M, Kimura F, Asano $T$ and Hayakawa M: Decreased serum adiponectin levels in patients with metastatic renal cell carcinoma. Jpn J Clin Oncol 38: 106-111, 2008. 